\title{
Effects of post-grazing forage mass on a beef cattle grazing system on Tanzânia grass pastures
}

\author{
Marco Antonio Penati ${ }^{1}$, Moacyr Corsi ${ }^{1}$, Guilhermo Francklin de Souza Congio ${ }^{1}$, Pedro Castro \\ de Almeida ${ }^{1}$, Ricardo Cazerta Duarte Goulart ${ }^{1}$, Miguel Miiti Shiota ${ }^{1}$
}

${ }^{1}$ Departamento de Zootecnia, Escola Superior de Agricultura "Luiz de Queiroz"/Universidade de São Paulo - Piracicaba, SP, Brasil.

\begin{abstract}
The objective of this study was to evaluate the effect of grazing intensity on herbage accumulation, animal performance, and total system yield on irrigated Tanzania grass pastures under rotational stocking. The experiment was conducted from October 1999 to January 2001, in a complete randomized block design with four replications. Treatments consisted of three grazing intensities, represented by the following quantities of green forage dry mass remaining after grazing: 1,000 (high intensity), 2,500 (intermediate intensity) and 4,000 (low intensity) $\mathrm{kg} \mathrm{ha}^{-1}$. Grazing cycles were of 36 days (33 rest and 3 grazing). The values observed at the end of the experiment for post grazing forage mass were close to the proposed values. Forage yield was $25,278,36,850$, and $34,144 \mathrm{~kg} \mathrm{DM} \mathrm{ha}^{-1}$, whereas animal performance was $0.398,0.541$, and $0.564 \mathrm{~kg} \mathrm{BW} \mathrm{day}^{-1}$ for high, intermediate and low intensities, respectively. Grazing intensity was positive related to the stocking rate $(6.5,5.2$ and 4.1 $\mathrm{AU} \mathrm{ha}^{-1}$ at high, intermediate and low intensities, respectively). Total system yield was not affected by treatments, ranging between 1,518 and $1,287 \mathrm{~kg} \mathrm{BW} \mathrm{ha}^{-1}$ year $^{-1}$.
\end{abstract}

Key Words: forage allowance, forage yield, grazing efficiency, irrigation, Panicum maximum

\section{Introduction}

Grazing is the main feeding system adopted by Brazilian beef cattle farmers due to its low cost that allows for higher profits compared with the other feeding options. Estimates indicate that $75 \%$ of cultivated lands in Brazil are occupied by pastures (Faria et al., 1996) and $88 \%$ of the meat produced in the country is originated from herds kept exclusively on pastures (Arruda, 1997).

Brazilian pastures are characterized by low-input systems that limit stocking rates to 0.86 animal units ( $450 \mathrm{~kg}$ cattle body weight) per hectare (CEPEA, 2007). Low soil fertility and inadequate pasture management practices can be indicated as the main factors that explain the low stocking rates.

Pasture system yields depend on the efficiency of three phases: forage growth, forage harvesting (grazing), and forage conversion into animal product, as initially proposed by Hodgson (1990). Those three phases are interrelated and antagonistic. Management practices to increase the efficiency of one phase tend to reduce the efficiency of the others. Therefore, partial inefficiencies in some phases have to be accepted to increase animal production of the

Received March 27, 2013 and accepted March 17, 2014

Corresponding author: mpenati@gmail.com

http://dx.doi.org/10.1590/S1516-35982014000600003

Copyright (@) 2014 Sociedade Brasileira de Zootecnia. This is an Open Access article distributed under the terms of the Creative Commons Attribution Non-Commercial License, which permits unrestricted non-commercial use, distribution, and reproduction in any medium, provided the original work is properly cited. whole system (Da Silva and Corsi, 2003). Research studies on grazing management have been trying to establish management targets that lead to the best combination of those three phases in order to maximize profitability while providing sustainability.

Post-grazing forage mass may influence forage yield, grazing efficiency and feed conversion (Parsons et al., 1988; Sbrissia et al., 2009). Post-grazing forage mass is hardly related to defoliation intensity and remaining/removed leaf area index (LAI) ratio. Sward photosynthesis is pointed not to be directly proportional to LAI removal, due to the preferential harvest of younger leaves compared with older leaves and those less exposed to light. Sward carbon assimilation depression due to defoliation would be less intense if a great proportion of young, still growing and well-lighted leaves remained after grazing, because of their higher photosynthetic efficiency. However, net forage accumulation in pastures under lenient defoliation could decrease in the long term, in response to the aging of tillers and leaves and increase in senescence rate (Da Silva and Sbrissia, 2001; Paiva, 2009; Sbrissia et al., 2009).

Although lenient defoliation can be related to harvesting nutritionally better plant components at each grazing event, in the long term this could lead to a reduction of the grazing layer thickness and forage density within it, besides a reduction in the leaf/steam ratio, depression of forage quality due to plant size and age, and increase in forage losses (Carvalho et al., 2009). 
The objective of this experiment was to evaluate effects of post-grazing forage mass on forage yield, animal performance, grazing efficiency, stocking rates, and total system yield of irrigated Tanzania grass pastures under rotational stocking.

\section{Material and Methods}

The experiment was conducted from October 30th, 1999 to January 3th, 2001 on Tanzania grass pastures (Panicum maximum Jacq. cv. Tanzania) located on Areão Farm, which belongs to Escola Superior de Agricultura "Luiz de Queiroz" - São Paulo University, in Piracicaba, São Paulo

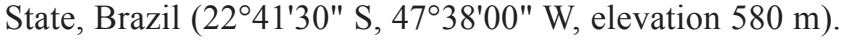
The soil at the experimental area was classified as a Clay Loam Red Nitisol (Embrapa, 1999) with the following chemical properties in the upper 20-cm layer: $\mathrm{pH}\left(\mathrm{CaCl}_{2}\right)$, 5.1; organic matter, $25 \mathrm{~g} \mathrm{dm}^{-3} ; \mathrm{P}, 19 \mathrm{mg} \mathrm{dm}^{-3}$; $\mathrm{S}_{-} \mathrm{SO}_{4}$, $30 \mathrm{mg} \mathrm{dm}{ }^{-3} ; \mathrm{K}, 4.2 \mathrm{mmol}_{\mathrm{c}} \mathrm{dm}^{-3} ; \mathrm{Mg}, 21 \mathrm{mmol}_{\mathrm{c}} \mathrm{dm}^{-3} ; \mathrm{Ca}$, $40.8 \mathrm{mmol}_{\mathrm{c}} \mathrm{dm}^{-3} ; \mathrm{H}+\mathrm{Al}, 35 \mathrm{mmol}_{\mathrm{c}} \mathrm{dm}^{-3} ; \mathrm{Cu}, 4.8 \mathrm{mg} \mathrm{dm}^{-3}$; $\mathrm{Fe}, 46 \mathrm{mg} \mathrm{dm}^{-3}$; Mn, $46 \mathrm{mg} \mathrm{dm}^{-3}$; and $\mathrm{Zn}, 4.8 \mathrm{mg} \mathrm{dm}^{-3}$.

The area was tilled from January to March, 1999. Limestone, simple superphosphate and potassium chloride were applied before seeding to reach $80 \%$ of base saturation, $30 \mathrm{mg} \mathrm{dm}^{-3} \mathrm{P}$, and $5 \% \mathrm{~K}$ considering the cationexchange capacity, following Corsi and Nussio (1993) recommendations. Micronutrients were applied as FTEBR-12 at a rate of $75 \mathrm{~kg} / \mathrm{ha}$ during pasture establishment.

Irrigation was managed based on soil water potential monitored with digital puncture tensiometers installed in ten series of six tensiometers each, at the following depths: $0.1,0.2,0.4,0.6,0.8$, and $1.0 \mathrm{~m}$. The tensiometer measures were recorded daily, and irrigation was conducted when average tension at $0.2 \mathrm{~m}$ reached -0.3 to $-0.4 \mathrm{Mpa}$ of soil water potential (Xavier et al., 2004).

The experiment was conducted as a completely randomized block design, with four blocks and three treatments: $1,000,2,500$, and $4,000 \mathrm{~kg} \mathrm{ha}^{-1}$ of post-grazing green forage dry matter (GFDM), which represented high, intermediate and low grazing intensities, respectively.

The experimental area was established on a center pivot irrigation system, and was divided into 12 slices of 0.4 ha each on a "pie" pattern. All slices were subdivided into three paddocks of equal size totaling 36 paddocks ( $0.133 \mathrm{ha})$. Every three adjacent slices formed a block, amounting to four blocks. Each slice of the block corresponded to one grazing intensity treatment. There were three treatment herds in the area, each one using one slice of each block (12 paddocks).

Grazing was conducted following a 36-days grazing cycle (33 rest and 3 grazing days). Animals had free access to water and loose mineral mixture in the paddocks. Available forage was evaluated before grazing by cutting all the forage above $5 \mathrm{~cm}$ from soil within five squared sample grids $\left(1 \mathrm{~m}^{2}\right.$ each). Grids were located on the paddocks on previous established positions at a transect line. Thirty sward height measurements were recorded using a ruler, always before and after paddock grazing.

The forage collected was weighted and subsampled in two parts, one to determine dry matter (DM) percentage and another to manually separate the plant part components: green leaf blade, green stem and dead material. Leaves or stems with more than $50 \%$ green were considered green leaf blade or green stem, respectively; they were considered dead material otherwise. Plant part components were then weighted and dried at $60{ }^{\circ} \mathrm{C}$ until constant weight to determine dry matter weight. The same procedure of cutting, separation and drying was used to characterize post-grazing forage mass.

Forage loss was determined using five squared grids $\left(4 \mathrm{~m}^{2}\right.$ each) systematically allocated in the paddocks using transect lines. The grids were cast before grazing, when all materials detached from the plants were removed from inside of it, making it clean. After grazing, all the forage material within the grids detached from the plants or attached to plants but damaged by animal activity were collected (Hillesheim, 1987). The material was weighted and dried to determine dry matter weight.

Stocking rate was adjusted every time a new paddock would be consumed, and was established using visual estimates made by three observers that considered: available forage dry matter, green material percentage, forage loss, daily animal intake of green forage dry matter (2.0 to $2.3 \%$ of $\mathrm{BW}$ ) and post-grazing forage mass of each treatment. Number of animals necessary to graze available forage during the three occupancy days was than calculated according to equation 1 :

$$
\begin{gathered}
\mathrm{NA}=\left(\left(\mathrm{PrGF} * \mathrm{GMP} * 100^{-1} *(100-\mathrm{LP}) * 100^{-1}\right)\right. \\
-\mathrm{PoGGF}) * \mathrm{OP}^{-1} * \mathrm{I}^{-1} * \mathrm{PS}
\end{gathered}
$$

in which: $\mathrm{NA}=$ number of animals per paddock; $\mathrm{PrGF}=$ pregrazing forage mass $\left(\mathrm{kg} \mathrm{DM} \mathrm{ha}{ }^{-1}\right)$; GMP $=$ green material percentage; $\mathrm{LP}=$ grazing loss percentage; $\mathrm{PoGGF}=$ postgrazing green forage mass $\left(\mathrm{kg} \mathrm{DM} \mathrm{ha}{ }^{-1}\right) ; \mathrm{OP}=$ occupation period (three days); $\mathrm{I}=$ estimated intake $\left(\mathrm{kg} \mathrm{DM}_{\text {head }}{ }^{-1}\right.$ day $\left.^{-1}\right)$; and $\mathrm{PS}=$ paddock size $(0.1333 \mathrm{ha})$.

Fertilizers were applied manually after every grazing cycle, using $334 \mathrm{~kg} \mathrm{ha}^{-1}$ of a 24-04-24 N-P $\mathrm{O}_{5}-\mathrm{K}_{2} \mathrm{O}$ formulation. At the end of the 14-month experimental period, total nutrients applied were: $960 \mathrm{~kg} \mathrm{~N} \mathrm{ha}^{-1}, 156 \mathrm{~kg} \mathrm{P}_{2} \mathrm{O}_{5} \mathrm{ha}^{-1}$, and $960 \mathrm{~kg} \mathrm{~K}_{2} \mathrm{O} \mathrm{ha}^{-1}$.

Castrated Nellore steers at ten months of age (initial age) and $227 \mathrm{~kg}$ average weight (initial weight) were used. 
Four test animals were selected for each treatment, with the objective to evaluate weight gain. Numbers of tester animals were calculated based on winter forage yield forecast, to avoid taking those animals out of the experimental area. Besides that, at the 9th grazing cycle, forage yield was too low, so it would be impossible to maintain the preestablished post-grazing forage mass. During this grazing cycle, test animals were kept out of the experimental area, and maintained on nearby pastures, supplemented with a diet to maintain $0.3 \mathrm{~kg} \mathrm{head}^{-1}$ day $^{-1}$ gains.

Animals were weighted at the end of each grazing cycle (36 days), after a 15-hour water-and feed-deprivation period. The animal yield per hectare was calculated by multiplying the average number of heads per hectare (adjusted by the average weight of test animals) by the weight gain of test animals during each grazing cycle. Total animal yield per hectare for the entire experimental period was calculated as the sum of all the grazing cycles.

Forage yield $\left(\mathrm{kg} \mathrm{DM} \mathrm{ha}^{-1}\right)$ was calculated as the difference between the pre-grazing forage mass and the post-grazing forage mass of the previous grazing cycle. Grazing efficiency was calculated by subtracting the forage loss from the forage yield of its respective grazing cycle and dividing the resulting value by the forage yield of the respective grazing cycle. Forage allowance was calculated by dividing pre-grazing forage mass by the average animal weight during the occupation period (100 kg BW).

Grazing cycles were grouped in four seasons that best summarize the results and to facilitate the establishment of a parsimonious covariance structure. A previous exploratory analysis was conducted to verify the assumptions of the statistical model. Data were analyzed considering a complete randomized block design and the season effect was also evaluated. In the case of a significant treatment $\times$ season interaction, the treatment means were compared for each season, and the season effects were evaluated for each treatment, using Least Square means on Student's t-test considering a significance level of 5\%. The analyses were conducted using the GLM procedure of SAS software (Statistical Analysis System, version 6.10), as described by Lima (1996).

\section{Results and Discussion}

The average post-grazing forage mass values observed at the end of the experiment were close to the previously proposed values of 1,000 (high grazing intensity), 2,500 (intermediate intensity) and 4,000 (low intensity) $\mathrm{kg}$ of GFDM ha ${ }^{-1}$, although they varied across the seasons. Nevertheless, treatments were different when compared in each season, with the exception of season 3 , when low and intermediate intensities did not differ (Table 1).

Forage yield was lower at the highest grazing intensity. Stem and dead material yields were reduced at the highest compared with intermediate grazing intensity, but did not differ from the lowest grazing intensity. Leaf yield was not statistically affected by the grazing intensity (Table 2).

Post-grazing forage mass treatments associated with 33-day grazing cycles resulted in different pre-grazing and post-grazing sward heights (Table 3 ).

Animal weight gain was influenced by grazing intensity. The achieved performances ( 0.389 to $0.564 \mathrm{~kg} \mathrm{head}^{-1}$ day $\left.^{-1}\right)$ are below the potential of pasture-based systems, probably due to the grazing frequency (33 days), which may have led to a decrease in forage quality (chemical and structural). The high grazing intensity caused lower animal weight

Table 1 - Post-grazing forage mass

\begin{tabular}{lcccc}
\hline \multirow{2}{*}{ Season } & \multicolumn{2}{c}{ Proposed post-grazing forage mass $\left(\mathrm{kg} \mathrm{GFDM} \mathrm{ha}^{-1}\right)$} & \multirow{2}{*}{ Mean } \\
\cline { 2 - 4 } & 1,000 & 2,500 & 4,000 & \\
\hline 1 & $1,277 \mathrm{Cab}$ & $2,459 \mathrm{Bb}$ & $3,106 \mathrm{Ab}$ & 2,281 \\
2 & $1,763 \mathrm{Ca}$ & $3,346 \mathrm{Ba}$ & $5,335 \mathrm{Aa}$ & 3,481 \\
3 & $816 \mathrm{Bb}$ & $2,548 \mathrm{Aab}$ & $3,113 \mathrm{Ab}$ & 2,159 \\
4 & $1,210 \mathrm{Cab}$ & $3,306 \mathrm{Ba}$ & $5,471 \mathrm{Aa}$ & 3,329 \\
Mean & 1,266 & 2,915 & 4,256 & - \\
\hline
\end{tabular}

GFDM - green forage dry matter.

Means followed by different capital letters in the rows and lowercase letters in the columns differ at $5 \%$ by Student's t-test.

Season 1 - 10/30/99 to 02/14/00; Season 2 - 02/15/00 to 06/01/00; Season $3-06 / 02 / 00$ to $08 / 12 / 00$; Season $4-09 / 18 / 00$ to $01 / 03 / 01$

Table 2 - Forage and plant components yields $\left(\mathrm{kg} \mathrm{DM} \mathrm{ha}^{-1}\right)$, according to different post-grazing forage mass treatments

\begin{tabular}{lccc}
\hline \multirow{2}{*}{ Plant component } & \multicolumn{3}{c}{ Post-grazing forage mass $\left(\mathrm{kg} \mathrm{GFDM} \mathrm{ha}{ }^{-1}\right)$} \\
\cline { 2 - 4 } & 1,266 & 2,915 & 4,256 \\
\hline Leaf & $17,336 \mathrm{a}$ & $20,592 \mathrm{a}$ & $20,416 \mathrm{a}$ \\
Stem & $4,070 \mathrm{~b}$ & $6,457 \mathrm{a}$ & $4,928 \mathrm{ab}$ \\
Dead material & $3,663 \mathrm{~b}$ & $9,801 \mathrm{a}$ & $8,646 \mathrm{ab}$ \\
Total forage & $25,278 \mathrm{~b}$ & $36,850 \mathrm{a}$ & $34,144 \mathrm{a}$ \\
\hline
\end{tabular}

DM - dry matter; GFDM - green forage dry matter.

Means followed by different letters in the rows differ at $5 \%$ by Student's t-test;

Table 3 - Effects of post-grazing forage mass on grazing system variables

\begin{tabular}{|c|c|c|c|}
\hline & \multicolumn{3}{|c|}{$\begin{array}{l}\text { Post-grazing forage mass } \\
\left(\mathrm{kg} \mathrm{GFDM} \mathrm{ha}{ }^{-1}\right)\end{array}$} \\
\hline & 1,266 & 2,915 & 4,256 \\
\hline Pre-grazing sward height $(\mathrm{cm})$ & $45 \mathrm{c}$ & $63 \mathrm{~b}$ & $71 \mathrm{a}$ \\
\hline Post-grazing sward height $(\mathrm{cm})$ & $19 \mathrm{c}$ & $34 \mathrm{~b}$ & $46 \mathrm{a}$ \\
\hline Forage allowance & & & \\
\hline$\left(\mathrm{kg}\right.$ GFDM $\left.100 \mathrm{~kg} \mathrm{BW}^{-1} \mathrm{day}^{-1}\right)$ & $9.4 \mathrm{c}$ & $18.4 \mathrm{~b}$ & $27.6 \mathrm{a}$ \\
\hline Animal performance $\left(\mathrm{kg} \mathrm{head}^{-1} \mathrm{day}^{-1}\right)$ & $0.398 \mathrm{~b}$ & $0.541 \mathrm{a}$ & $0.564 \mathrm{a}$ \\
\hline Grazing efficiency (\%) & $75 \mathrm{a}$ & $67 \mathrm{a}$ & $47 b$ \\
\hline Stocking rate (AU hectare $\left.{ }^{-1}\right)$ & $6.5 \mathrm{a}$ & $5.2 \mathrm{~b}$ & $4.1 \mathrm{c}$ \\
\hline System yield $\left(\mathrm{kg} \mathrm{BW} \text { hectare }{ }^{-1}\right)^{1}$ & $1,518 \mathrm{a}$ & $1,419 \mathrm{a}$ & $1,287 \mathrm{a}$ \\
\hline
\end{tabular}


gain than the intermediate and low grazing intensities (Table 3). Those results can be explained by the different forage allowances imposed by the treatments. Animal performance responses to forage allowance may be affected by the average quality of the allowed forage and selection possibilities. The forage-allowance results were positively related to post-grazing forage mass (Table 3 ).

Almeida et al. (2000) reported a quadratic effect of forage allowance on animal weight gain, and found that $11.3 \mathrm{~kg}$ of leaf blade dry matter $100 \mathrm{~kg} \mathrm{BW}^{-1}$ day $^{-1}$ maximized performance of crossbred Charolais $\times$ Nellore cattle. Hodgson (1990) showed that animal performance increases at declining rates with increasing forage allowances, and suggested a plateau between 10 and $12 \mathrm{~kg}$ of DM $100 \mathrm{~kg} \mathrm{BW}^{-1}$ day $^{-1}$ for various animal categories. Nevertheless, Combellas and Hodgson (1979) asserted that interpreting forage allowance results of different experiments/situations is difficult. According to Humphreys (1991), this difficulty is a consequence of the different forage evaluation methods.

Post-grazing height was a consequence of experimental treatments, which can affect regrowth speed. Initially, low intensity grazing leads to higher regrowth speed, in response to higher residual LAI. However, this variable is also influenced by tiller age (LAI quality), so if lenient grazing is used for successive grazing cycles, tiller average age increases and leaf photosynthetic efficiency decreases, which could reduce the pasture regrowth speed (Paiva, 2009; Sbrissia et al., 2009).

Post-grazing height interferes with animal intake mainly by changing the sward layers explored during the grazing process. High-intensity grazing forces animals to explore lower strata of the sward, where the nutritive value is usually lower (Carvalho et al., 2001; Carvalho et al., 2009), thereby limiting intake and animal performance, but increasing grazing efficiency and allowing for higher stocking rates (Trindade, 2007). Forage-quality problems (lower intake and nutritional value) related to exploitation of lower strata of the sward tend to increase with longer resting periods or higher pre-grazing sward heights.

Grazing efficiency was reduced at the low grazing intensity as compared with the high and intermediate intensities (Table 3). Higher post-grazing heights have been related to higher amounts of forage losses and reduced grazing efficiency (Hillesheim, 1987; Carnevalli, 2003; Almeida, 2011), which can be related to consumption of a reduced proportion of the accumulated forage and with differences in sward structure that promote losses due to senescence and trampling.

Stocking rates were inversely related to post-grazing forage mass (Table 3 ). The higher stocking rates observed at higher grazing intensities can be explained by the increased grazing efficiencies. In order to establish the lower postgrazing forage mass treatments (high grazing intensity), it was necessary to increase stocking rates, which in turn forced the animals to eat a greater proportion of available forage, decreasing forage allowance an increasing grazing efficiency. Braga et al. (2007) showed that increasing forage allowances were related to decreasing grazing efficiencies in an exponential pattern.

The total system yield was not affected by treatments, ranging from 1,287 to $1,518 \mathrm{~kg} \mathrm{BW} \mathrm{ha}^{-1}$ (Table 3). These results can be explained by a compensatory balance of animal performance and stocking rate. Although higher grazing intensity reduced animal performance, this effect was compensated by the higher stocking rate; whereas at lower grazing intensity, the low stocking rate was compensated by higher animal weight gain. Carnevalli et al. (2001) also observed increasing animal performance and reducing stocking rates at higher forage allowances working with sheep at Tifton 85 (Cynodon dactylon) pastures under continuous grazing. Similar results are described by Hodgson (1985), for Perennial ryegrass (Lollim perenne), and in the classic study of Mott (1960).

\section{Conclusions}

Forage yield is influenced by grazing intensity.

Grazing efficiency is reduced at lower grazing intensities.

At the evaluated ranges, variations in post-grazing forage mass influence animal performance and stocking rates inversely, whereas total system yield can be similar.

Production systems based on pastures can reach high animal productivities, over 1,285 kg BW hectare ${ }^{-1}$ year $^{-1}$.

\section{Acknowledgments}

The authors thank the São Paulo Research Foundation (Fundação de Amparo à Pesquisa do Estado de São Paulo, FAPESP) for the financial support, and the group of undergraduate students Projeto CAPIM for helping with the research routine.

\section{References}

Almeida, E. X.; Maraschin, G. E.; Harthmann, O. E. L.; Ribeiro Filho, H. M. N. and Setelich, E. A. 2000. Oferta de forragem de capimelefante anão Mott e o rendimento animal. Revista Brasileira de Zootecnia 29:1288-1295.

Almeida, P. C. 2011. Respostas de Panicum maximum cv. Tanzânia à associações entre adubação e severidade de desfolha. Dissertação 
(M.Sc.). Escola Superior de Agricultura "Luiz de Queiroz", Universidade de São Paulo, Piracicaba.

Arruda, Z. J. 1997. A pecuária de corte no Brasil e resultados econômicos de sistemas alternativos de produção. p.259-273. In: Anais do 4ํㅗำósio sobre Pecuária de Corte. FEALQ, Piracicaba.

Braga, G. J.; Pedreira, C. G. S.; Herling, V. R. and Luz, P. H. C. 2007. Eficiência de pastejo de capim-marandu submetido a diferentes ofertas de forragem. Pesquisa Agropecuária Brasileira 42:1641-1649.

Carnevalli, R. A. 2003. Dinâmica da rebrotação de pastos de capimmombaça submetidos a regimes de desfolhação intermitente. Tese (D.Sc.). Escola Superior de Agricultura "Luiz de Queiroz", Universidade de São Paulo, Piracicaba.

Carnevalli, R. A.; Da Silva, S. C.; Fagundes, F. L.; Sbrissia, A. F.; Carvalho, C. A. B.; Pinto, L. F. M. and Pedreira, C. G. S. 2001. Desempenho de ovinos e respostas de pastagens de Tifton 85 (Cynodon spp.) sob lotação contínua. Scientia Agrícola 58:7-15.

Carvalho, P. C. F.; Ribeiro Filho, H. M. N.; Poli, C. H. E. C.; Moraes, A. and Delagarde, R. 2001. Importância da estrutura da pastagem na ingestão e seleção de dietas pelo animal em pastejo. p.853-871. In: Produção animal na visão dos brasileiros. Mattos, W. R. S. et al., eds. FEALQ, Piracicaba.

Carvalho, P. C. F.; Trindade, J. K.; Da Silva, S. C.; Bremm, C.; Mezzalira, J. C.; Nabinger, C.; Amaral, M. F.; Carassai, I. J.; Martins, R. S.; Genro, T. C. M.; Gonçalves, E. N.; Amaral, G. A.; Gonda, H. L.; Poli, C. H. E. C. and Santos, D. T. 2009. Consumo de forragem por animais em pastejo: analogias e simulações em pastejo rotativo. p.61-93. In: Anais do 25은 Simpósio sobre Manejo da Pastagem. FEALQ, Piracicaba.

CEPEA - Centro de Pesquisa em Economia Agrícola. 2007. Informações recentes às variações dos custos de produção de carne bovina em Junho de 2007. Available at: <www.cepea.esalq.usp.br/ comunicacao/Cepea CustosProdPec Julho07.doc>. Accessed on: Mar. 30, 2008.

Combellas, J. and Hodgson, J. 1979. Herbage intake and milk production by grazing dairy cows 1 . The effects of variation in herbage mass and daily herbage allowance in a short-term trial. Grass and Forage Science 34:209-214.

Corsi, M. and Nussio, L. G. 1993. Manejo do capim elefante: correção e adubação do solo. p.87-116. In: Anais do 10ํㅗำ Simpósio sobre Manejo da Pastagem. FEALQ, Piracicaba.

Da Silva, S. C. and Corsi, M. 2003. Manejo do pastejo. p.155-186. In: Anais do $20^{\circ}$ Simpósio sobre Manejo da Pastagem. FEALQ, Piracicaba.

Da Silva, S. C. and Sbrissia, A. F. 2001. A planta forrageira no sistema de produção. p.71-88. In: Anais do 170 Simpósio sobre Manejo da Pastagem. FEALQ, Piracicaba.
EMBRAPA - Empresa Brasileira de Pesquisa Agropecuária. Centro Nacional de Pesquisa de Solos. 1999. Sistema brasileiro de classificação de solos. Embrapa Solos, Rio de Janeiro.

Faria, V. P.; Pedreira, C. G. S. and Santos, F. A. P. 1996. Evolução do uso de pastagens para bovinos. p.1-14. In: Anais do 13 Simpósio sobre Manejo da Pastagem. FEALQ, Piracicaba.

Hillesheim, A. 1987. Fatores que afetam o consumo e perdas de capim elefante (Pennisetum purpureum Schum.) sob pastejo. Dissertação (M.Sc.). Escola Superior de Agricultura "Luiz de Queiroz", Universidade de São Paulo, Piracicaba.

Hodgson, J. 1985. The significance of sward characteristics in the management of temperate sown pastures. p.63-66. In: Proceedings of the 15th International Grassland Congress, Kyoto. Japanese Society of Grassland Science, Nishinasuno, Tochini-ken, Japan.

Hodgson, J. 1990. Grazing management: Science into pratice. Longman Scientific and Technical, Longman group, New York.

Humphreys, L. R. 1991. Tropical pasture utilization. Cambridge University Press, Cambridge.

Lima, C. G. 1996. Análise de dados longitudinais provenientes de experimentos em blocos casualizados. Tese (D.Sc.). Escola Superior de Agricultura "Luiz de Queiroz", Universidade de São Paulo, Piracicaba.

Mott, G. O. 1960. Grazing pressures and the measurement of pastures production. p.606-611. In: Proceedings of the 8th International Grassland Congress, Reading.

Paiva, A. J. 2009. Características morfogênicas e estruturais de faixas etárias de perfilhos em pastos de capim-marandu submetidos à lotação contínua e ritmos morfogênicos contrastantes. Dissertação (M.Sc.). Escola Superior de Agricultura "Luiz de Queiroz", Universidade de São Paulo, Piracicaba.

Parsons, A. J; Johnson, I. R. and Harvey, A. 1988. Use of a model to optimize the interaction between frequency and severity of intermittent defoliation to provide a fundamental comparison of the continuous and intermittent defoliation of grass. Grass and Forage Science 43:49-59.

Sbrissia, A. F.; Da Silva, S. C.; Nascimento Junior, D. and Pereira, L. E. T. 2009. Crescimento da planta forrageira: aspectos relativos ao acúmulo e valor nutritivo da forragem. p.37-59. In: Anais do 25은 Simpósio sobre Manejo da Pastagem. FEALQ, Piracicaba.

Trindade, J. K. 2007. Modificações na estrutura do pasto e no comportamento ingestivo de bovinos durante o rebaixamento do capim-marandu submetido a estratégias de pastejo rotacionado. Dissertação (M.Sc.). Escola Superior de Agricultura "Luiz de Queiroz”, Universidade de São Paulo, Piracicaba.

Xavier, A. C.; Coelho, R. D.; Lourenço, L. F. and Machado, R. E. 2004. Manejo da irrigação em pastagem irrigada por pivô-central. Revista Brasileira de Engenharia Agrícola e Ambiental 8:233-239. 